
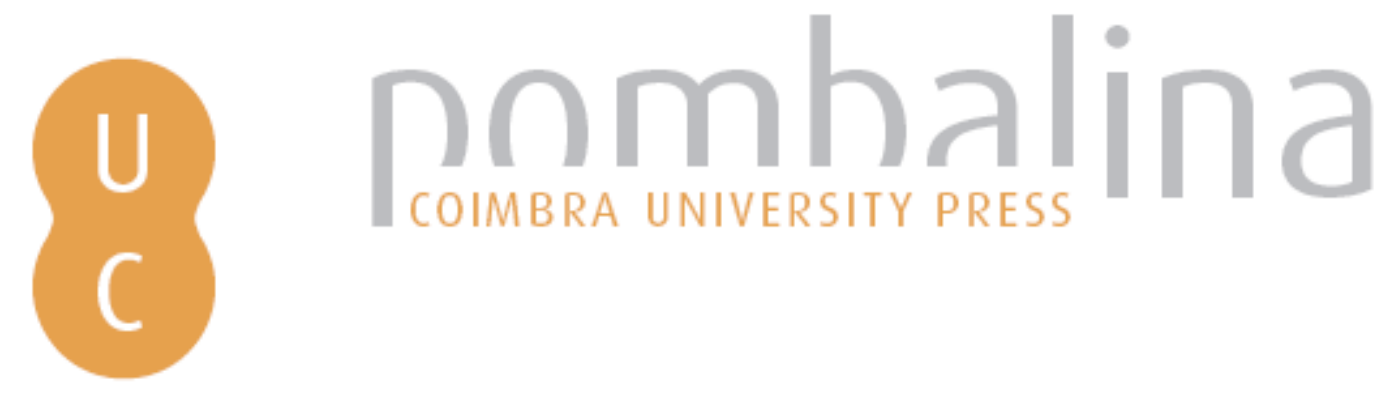

\title{
Fire, landscape pattern and biodiversity: using fire for conservation in a south- eastern Australian ecosystem
}

Autor(es): $\quad$ York, Alan; Stefano, Julian Di; Sitters, Holly; Swan, Matthew

Publicado por: Imprensa da Universidade de Coimbra

URL

persistente: URI:http://hdl.handle.net/10316.2/44662

DOI: $\quad$ DOI:https://doi.org/10.14195/978-989-26-16-506_145

Accessed : $\quad$ 26-Apr-2023 13:12:27

A navegação consulta e descarregamento dos títulos inseridos nas Bibliotecas Digitais UC Digitalis, UC Pombalina e UC Impactum, pressupõem a aceitação plena e sem reservas dos Termos e Condições de Uso destas Bibliotecas Digitais, disponíveis em https://digitalis.uc.pt/pt-pt/termos.

Conforme exposto nos referidos Termos e Condições de Uso, o descarregamento de títulos de acesso restrito requer uma licença válida de autorização devendo o utilizador aceder ao(s) documento(s) a partir de um endereço de IP da instituição detentora da supramencionada licença.

Ao utilizador é apenas permitido o descarregamento para uso pessoal, pelo que o emprego do(s) título(s) descarregado(s) para outro fim, designadamente comercial, carece de autorização do respetivo autor ou editor da obra.

Na medida em que todas as obras da UC Digitalis se encontram protegidas pelo Código do Direito de Autor e Direitos Conexos e demais legislação aplicável, toda a cópia, parcial ou total, deste documento, nos casos em que é legalmente admitida, deverá conter ou fazer-se acompanhar por este aviso.

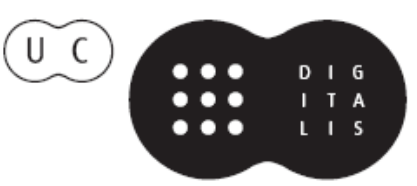




\section{ADVANCES IN}

\section{FOREST FIRE RESEARCH}

\section{8}

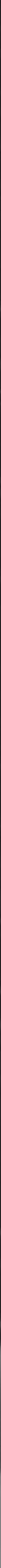


Short contribution - Fuel Management

Fire, landscape pattern and biodiversity: Using fire for conservation in a south-eastern Australian ecosystem

\author{
Alan York*; Julian Di Stefano; Holly Sitters; Matthew Swan \\ School of Ecosystem and Forest Sciences, University of Melbourne. 4 Water Street Creswick VIC Australia \\ 3363, \{alan.york@unimelb.edu.au*\}
}

Keywords: animal diversity, fire mosaic, pyrodiversity, species richness

\title{
1. Introduction
}

Fire is an important process that influences species and ecosystems worldwide. By changing the availability of resources for organisms in space and time, fire has the potential to be a powerful driver of species diversity. Biodiversity conservation in fire-prone environments presents a challenge for management because it is unclear how best to apply planned burns to the landscape. It is widely assumed that spatially and temporally variable fire regimes benefit biodiversity conservation. This is based on ecological theory, which predicts positive associations between species diversity and environmental heterogeneity. A mosaic of fire histories constitutes a mosaic of environmental states, which is generated by differences in the resetting, or partial resetting, of the successional process in time and space.

Although the notion that variable fire regimes benefit biodiversity is grounded in ecological theory, it has rarely been tested. As the application of planned (prescribed) fire is becoming more common amid forecasted increases in frequency and severity of wildfire under climate change, we need to better understand the relationship between fire regimes and biodiversity. The principal aim of this research was to test the theorised relationship between native animal diversity and landscape spatial pattern complexity within a fire-prone ecosystem. We sought to examine how animal communities are influenced by (i) fire-mediated spatial pattern ('pyrodiversity'), which is subject to control by land managers, and (ii) spatial pattern in vegetation type, which remains relatively static. We differentiated between these two influences by mapping fire age class and vegetation type separately, and tested predictions about the response of animal diversity to the observed spatial patterns.

\section{Methods}

This study was conducted in a 59,000 ha section of the Otway Ranges in southern Victoria, Australia. The climate of this region is temperate with cool wet winters and warm dry summers. In response to an elevation and rainfall gradient, vegetation communities change from areas of treeless heath in the north east to tall wet forests in the south. The study area has been subject to wildfires in 1939, 1967 and 1983, with prescribed fire undertaken extensively for fire mitigation purposes over the last 10 years.

For the purposes of this study we defined 100 ha 'landscapes' as the sampling unit. Thirty-six landscapes ('mosaics') were stratified according to the composition of both fire age classes and vegetation types. Five sub-sampling sites based around $100 \mathrm{~m}$ transects were established in each mosaic (Figure 1). We surveyed diurnal birds using two 10 minute interval counts at the 20 and $80 \mathrm{~m}$ marks of each transect (Sitters et al. 2014a,b). We surveyed terrestrial mammals using a combination of trapping and wildlife camera detection (Swan 2014, Swan et al. 2015). We also quantified a number of habitat variables along each transect. We used generalized linear mixed models to investigate how animals respond to landscape diversity and configuration. We also used generalized additive mixed models to explore relationships between fire, habitat structure and animal abundance. 


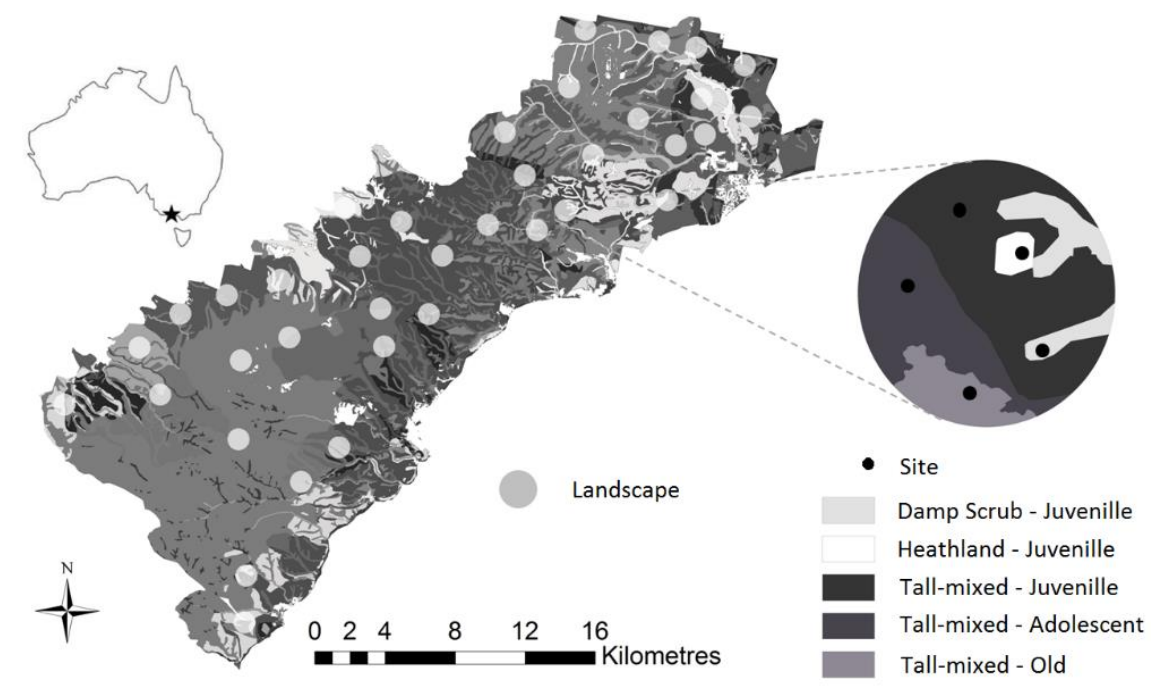

Figure 1 - Location of the study area in the Otway Ranges, southern Australia showing study landscapes. Different shades represent combinations of vegetation type and age class. The blowout shows a single landscape (mosaic) containing three vegetation types and three age classes.

\section{Results}

For birds, species richness was positively associated with fire age class diversity, age class configuration and vegetation type diversity. Habitat structure variables predicted the occurrence of 13 bird species, however overall, time since fire was a poor predictor.

We found that although time since fire was moderately correlated with habitat structure, it was a poor surrogate for mammal occurrence. Variables representing habitat structure were better predictors. Overall, terrestrial mammal diversity was not related to pyrodiversity but to spatial heterogeneity in habitat structure.

\section{Discussion}

This study is one of a few landscape-scale analyses to provide empirical support for the widely held assumption that spatially variable fire regimes can increase the diversity of faunal assemblages. Managers can potentially increase bird species richness by increasing both the diversity of fire age classes, and the complexity of age class configuration, within relatively small areas. However, our results suggest that time since last fire, a measure commonly used in management, is unlikely to be a useful surrogate for either birds or ground dwelling mammals. At landscape scales, fire can be used to positively influence mammal diversity by increasing the spatial variability in structure.

Time since fire is currently used by Australian land managers to define post-fire vegetation growth stages. The application of planned fire to create a mosaic of growth stages underpins current ecological fire strategies. However, our research has demonstrated that time since fire is, by itself, a poor surrogate for faunal occurrence in these forests. To better conserve biodiversity in these landscapes we need a improved understanding of the relationship between fire regime variables and habitat structure. More accurate mapping of fire severity and patchiness, and the inclusion of these factors in fire management planning, is likely to lead to a more sophisticated understanding of the role of fire in conserving native animal communities.

\section{References}

Sitters H, Christie F, Di Stefano J, Swan, M, Penman T, Collins P, York A (2014a) Avian responses to the diversity and configuration of fire age classes and vegetation types across a rainfall gradient. Forest Ecology and Management 318, 13-20. 
Sitters H, Christie F, Di Stefano J, Swan M, Collins P, York A (2014b) Associations between occupancy and habitat structure can predict avian responses to disturbance: implications for conservation management. Forest Ecology and Management 331, 227-236.

Swan M (2014) Interactions between fire, environmental heterogeneity and ground-dwelling mammals. Unpubl. PhD Thesis. Department of Forest and Ecosystem Science, The University of Melbourne, Australia.

Swan M, Christie F, Sitters H, York A, Di Stefano J (2015) Predicting faunal fire responses in heterogeneous landscapes: the role of habitat structure. Ecological Applications 25, 2293-2305. 